\title{
PRELIMINARY SURVEY OF THE PLANORBIDIC FAUNA IN SANTA CATARINA ISLAND, SANTA CATARINA, BRAZIL
}

\section{KAREN SCHMIDT ESPINDOLA; PAULO ROBERTO PETERSEN HOFMANN \& MARIA MARQUES MACHADO}

\begin{abstract}
Departamento de Biologia, Universidade Federal de Santa Catarina, Caixa Postal 476, 88049 Florianópolis, $\mathrm{SC}$, Brasil
\end{abstract}

The molluscs belonging to the Planorbidae family, so far identified in Brazil, are distributed in six genera: Drepanotrema, Plesiophysa, Acrorbis, Antillorbis, Helisoma and Biomphalaria (W. L. Paraense, 1975, Arq. Mus. Nac., 55: 105-128). The latter stands out in importance because it comprises some species responsable for the transmission of Schistosoma mansoni (H. M. S. Teles, 1988, Ciência e Cultura, 40: 373.379).

The geographical distribution of the Brazilian planorbids has been continuously investigated, and new occupation places described (W. L. Paraense, 1986, Anais Acad. Min. Med., Suppl. 14: 117-128).

The survey was made in canals, irrigation ditches and ravines of eight strategic places of the Island of Santa Catarina: Vargem Grande, Vargem Pequena, Ratones and Canasvieiras, in the North; Corrego Grande in the Midland; Rio Tavares, Campeche and Ribeirāo da Ilha, in the South. Samples were collected during the period between December/1988 and October/1989, dissected in the laboratory, and sent to Dr W. L. Paraense (Instituto Oswaldo Cruz - FIOCRUZ) and to Dr J. F. Vaz (Instituto de Biociências da USP) for confirmation of the specific identification.

Except for Canasvieiras, where 53 specimens of Drepanotrema sp. were collected, no planorbids were found, of any genus, in Campeche or in the places at the North. Populations of Biomphalaria oligoza were found in Rio Tavares and Ribeirão da Ilha, 8 and 14 specimens being collected, respectively. Córrego Grande showed a high population density of $B$. tenagophila, with 1,303 specimens collected, together with 25 of Drepanotrema cimex. The latter was also collected in Ribeirão da Ilha, with 19 specimens.

Due to the knowledge of $B$. tenagophila as a vector of schistosomiasis (P. R. P. Hofman et al., 1985, Ciência e Cultura, 37: 1286-1288), Córrego Grande becomes very important on the medical and sanitary point of view. Studies on the natural and experimental infection of this kind of molluscs are being developed by our group. 